\title{
Д.Е. Кузнецов
}

\section{ПРОБЛЕМЫ В ДЕЯТЕЛЬНОСТИ МИЛИЦИИ ЗАПАДНОЙ СИБИРИ (1925-1932 гг.)}

\begin{abstract}
Рассматриваются проблемы недобросовестного исполнения сотрудниками милиции своих служебных обязанностей в период 1925-1932 гг. Особое внимание уделяется причинам появления данных недостатков, а также инструментам в борьбе с ними в исследуемый период. Приводятся конкретные примеры преступлений и иных нарушений, совершаемых милиционерами. Отдельно выделяется употребление работниками милиции алкоголя как фактор, провоцирующий совершение преступных действий. Затрагивается метод использования репрессивных мер в борьбе с нарушениями со стороны милиционеров.

Ключевые слова: советская милиция; Западная Сибирь; преступление; проблемы.
\end{abstract}

На сегодняшний день правоохранительные органы, в частности российская полиция, находятся под пристальным вниманием государства и общества. В условиях современности к полицейским предъявляются все новые и новые требования, так как, по мнению граждан, не все правоохранители способны решать возложенные на них ответственные задачи. Схожие проблемы имели место в период становления советской милиции. В такой ситуации ценным является опыт прошлого, обращение к которому может быть использовано для разрешения и недопущения схожих проблем, чем обусловливается актуальность выбранной тематики исследования. Изучение становления милиции именно в Западной Сибири требует углубленного изучения по причине специфики западносибирского региона, а именно: обширности территории, низкой плотности населения, высокой концентрации ссыльного и преступного элемента, наличие контрреволюционных сил и пр. Не случаен и выбор исследуемого периода, который начинается с объединения ряда субъектов в Сибирский край 25 мая 1925 г., что влекло за собой существенные изменения в структуре милиции, и ограничивается 1932 г., так как именно в это время стали видны первые плоды реорганизации органов милиции, начатой 25 мая 1931 г. [1. Л. 57]. В указанное время явственно проявились все ошибки и недочеты в деятельности милиции, во многом по причине которых и была осуществлена реорганизация.

Попытка комплексного изучения проблем в деятельности советской милиции Западной Сибири середины 1920-х - 1930-х гг. делается впервые. В советский период издавались работы по истории милиции с явными признаками идеологической марксистко-ленинской подоплеки. Немногочисленные работы постсоветского периода «грешат» излишней политизированностью, стремлением представить деятельность милиции как некую репрессивно-карательную структуру.

Перед советскими правоохранительными органами ставились сложные задачи, связанные с выполнением служебных обязанностей. Осложнялось формирование дееспособной милиции обширностью территории Западной Сибири, суровым климатом, экономической неразвитостью региона, разрушительными последствиями гражданской войны.

Нередко встречались в деятельности западносибирской милиции волокита и бюрократизм. Процент раскрываемости уголовных преступлений оставался низким, высылка уголовного элемента из региона была неорганизованна, связи с общественностью были часто формальными, квалификация работников милиции и уголовного розыска недостаточной [2. Л. 77].

Одной из основных проблем в работе правоохранительных органов в Сибири был дефицит квалифицированных кадров. В милицию приходили малограмотные, имеющие слабые представления о милицейской службе молодые люди [3. С. 59]. При приеме на службу превалировал классовый подход. Представители «эксплуатировавших классов» не могли рассчитывать на милицейскую должность. В то же время выходцы из среды беднейшего крестьянства и пролетариата, несмотря на уголовное прошлое и серьезные проблемы со здоровьем, принимались на службу на «ура».

К основным проблемам в работе рабочекрестьянской милиции (РКМ) начальник милиции Сибирского края относил:

1) слабую подготовку командного и руководящего состава административных органов;

2) высокий процент совершения преступления самими сотрудниками милиции;

3) недостаточное обеспечение снаряжением (до 65\%), в частности канцелярскими принадлежностями, служебной документацией (бланками, протоколами), конским составом, вооружением и необходимыми для его обслуживания принадлежностями;

4) малограмотность младших милиционеров (до 90\%), незнание ими своих служебных обязанностей;

5) слабую дисциплину, выражавшуюся в небрежном ношении форменной одежды, формальном отношении к ведению служебной документации и инструктажам;

6) бытовую неустроенность сотрудников, а именно отсутствие служебного жилья, а также его несоответствие требованиям санитарии и гигиены;

7) отсутствие плана в деятельности отделов и отчетов перед населением [4. Л. 10-30]. 
Данные недостатки значительно усиливались на фоне высокого уровня преступности в регионе. Количество тяжких преступлений, таких как убийства, бандитизм, разбой, кража личной и государственной собственности в 20-е - 30-е гг. прошлого века было значительным. Кроме того, широкое распространение получили такие негативные явления, как пьянство и хулиганство, попрошайничество, бродяжничество, спекуляция, нарушение паспортного режима.

Состояние здоровья и физическая развитость действующих сотрудников милиции были далеки от идеала. Произведенное в 1931 г. освидетельствование физического состояния группы руководящих сотрудников районов выявило из 341 милиционера здоровых лишь 41. 20-25\% от общего числа оказались абсолютно не пригодными к милицейской службе. Усугубляло проблему отсутствие оздоровительных мероприятий, а также регулярных медицинских осмотров в органах милиции [5. Л. 42].

Вследствие нерешенных кадровых проблем в деятельности милиции был крайне низкий уровень исполнительской дисциплины. Многие милиционеры предпочитали решать личные дела в служебное время, спали на посту, халатно работали с документами. Так, младший милиционер ведомственной милиции Черлакского района Кусков допустил побег кулака, так как вместо охраны арестованных совершал половые акты с одной из арестованных женщин [Там же. Л. 134-134 об.].

На повестке дня оставался вопрос слабой дисциплины в рядах милиции. Далеко не все сотрудники осознавали значимость возложенных на них обязанностей, не до конца понимали понятие «служебный долг». В следствие чего в 1927 г. за пьянство увольнению из РКМ подверглись начальник 1-го отделения милиции Барнаула Шипицин и начальник Ребрихинского управления Малахов. Доказательством может служить и тот факт, что в период рейдов против самогонщиков были выявлены случаи употребления конфискованного самогона самими милиционерами [6. Л. 25, 30].

Ряд милиционеров злоупотребляли своим служебным положением. Помощник начальника Ключевского райуправления милиции Пугачев был осужден на четыре года за избиение кулака при выселении, нанесение телесных повреждений нетрезвому гражданину, угрозу оружием милиционеру, избиение члена сельсовета, причинение телесных повреждений контролеру сельского клуба (сбросил его с крыльца) [5. Л. 74].

Имело место и участие в преступных действиях самих стражей закона:

1. В 1928 г. в Барабинском округе Татарского района сотрудники милиции организовали преступное сообщество и в течение двух лет промышляли хищениями государственной собственности. Кроме прочего, ими было похищено 12 наганов. Только на увеселительные мероприятия за счет похищенных средств милиционерами-«оборотнями» было потрачено не менее 1900 руб. Показателен тот факт, что данные события происходили с ведома и при непосредственном участии начальника милиции Межецкого. Данная банда была ликвидирована в 1930 г. [7. Л. 19-20, 28].

2. Во второй половине 1920-х гг. два милиционера Рубцовского округа принимали деятельное участие в координации бандитской группы Кузьменко [8. Л. 79-80].

3. В первой половине 1930-х гг. участковый инспектор Прокопьевского РУМ, оставаясь на службе в милиции, организовал банду, в составе которой совершал грабежи и даже убийство [5. Л. 44].

Многие должностные преступления в исследуемый период совершались в состоянии опьянения или же становились результатом систематического пьянства. Так, уполномоченный Топкинского района Богрянов при допросе избивал невинных граждан, грозил им расстрелом. В итоге отпускал, присваивая деньги и водку.

Пьянство и половой разврат по значительному большинству дел были одной из причин совершения должностных преступлений. Огласку получили случаи попыток изнасилования женщин сотрудниками милиции. Женщин задерживали под выдуманными предлогами с целью вступления с ними в половую связь, шантажируя возбуждением уголовного дела [Там же. Л. 133].

Низкая раскрываемость преступлений порождала безнаказанность для преступников, а также рисовала образ беспомощности правоохранителей в глазах граждан. Розыск преступников был неудовлетворительным, скорость и качество проведения дознания и следствия были низкими [Там же. Л. 135].

Пытаясь увеличить раскрываемость преступлений, ряд милиционеров намеренно не регистрировали обращение граждан о совершенных преступлениях в книгу учета. В результате искажалась общая криминогенная картина в регионе, снижалось доверие населения к органам милиции.

Серьезным недочетом в деятельности милиции являлся порядок рассмотрения дел об административных правонарушениях. Так, в РУМе Коченевского района данные дела рассматривались одним начальником управления милиции; в ряде районов вместо представителей общественности в комиссиях по рассмотрению данных дел принимали участие следователи или работники Райисполкомов, в Чумышском районе такая комиссия вообще существовала формально на бумаге; в некоторых районах начальники управлений милиции, не вникая в дела, занимались только «штамповкой постановлений в соответствии с указаниями» [Там же. Л. 31].

Все это являлось следствием низкого уровня профессионализма сотрудников милиции, сопровождавшегося неумением или слабым использованием в работе научно-технических методов раскрытия преступлений [9. Л. 86]. Редко применялись собаки-ищейки в оперативной деятельности Уголовного розыска. В то же время сотрудники использовали неправомерные мето- 
ды допроса, что влекло за собой нарушение социалистической законности и злоупотребления служебным положением. Осмотр места происшествия производился сотрудниками милиции неумело [10. Л. 71 об.].

Отсутствие профессиональной подготовки, незнание правил порядка применения оружия и неумелое обращение с ним вели часто к трагическим последствиям. Так, например, милиционеры Логинов и Чебанов, пытаясь усмирить разбушевавшегося нетрезвого гражданина Шокинова в с. Алексеевском, погибли от пуль его нагана [11].

Имели место случаи незаконного и необдуманного применения оружия со стороны милиционеров. Причинами подобных случаев служили: несоблюдение правил применения оружия, превышение мер самообороны и превышение власти. Наиболее характерными случаями являлись следующие: в Ачинском округе милиционер стрелял в вызванного на допрос гражданина, ранив его; были случаи стрельбы в пьяных, нарушавших общественное спокойствие и тишину, которые не подчинялись требованиям милиционеров; в Ачинском и Барабинском округах имели место случаи убийств, совершенных милиционерами из низменных и личных побуждений [12. Л. 8-8 об.].

Приведенные примеры указывают на незнание правил применения оружия милиционерами, а также на халатное отношение сотрудников к инструктированию [13. Л. 61].

Нередки были случаи утраты оружия сотрудниками милиции по причинам небрежного обращения с ним, оставления без присмотра, передачи посторонним лицам. Так, младший милиционер Омского дивизиона Шумилов во время несения службы, находясь у себя на квартире, отдал свой револьвер пьяному товарищу, который ушел с ним и в итоге его потерял; старший милиционер третьего взвода милиции г. Омска хранил револьвер «Кольт» в незакрытом столе. В результате чего оружие было похищено неизвестными лицами [5. Л. 134 об.].

Существенным недостатком в работе РКМ было фактическое отсутствие полноценных контактов между милицией и уголовным розыском, с одной стороны, и народными массами - с другой. Данная тенденция вела к замкнутости и изолированности органов милиции от прочих структур и населения, а также к бюрократизации, что дискредитировало власть в глазах общественности. Опасным для сохранения прежде всего боеспособного уголовного розыска являлось необратимое изменение правосознания ряда сотрудников, происходило заимствование ими жизненных принципов из бандитской среды.

Заместитель Наркома внутренних дел РСФСР Егоров в августе 1928 г. обращал внимание руководителей сибирской милиции на возможную деформацию сотрудников уголовного розыска в связи с систематическими связями с преступным миром. Часть сотрудников поддавалась соблазну вступать в регулярные интимные отношения с занимающимися проституцией женщинами [14. Л. 185-186], брать взятки, вести разгульный образ жизни, не соответствующий образу блюстителя закона.

Пытаясь повысить дисциплину среди сибирских милиционеров, в отношении нарушителей применялись различные виды наказания вплоть до увольнения из органов внутренних дел и возбуждения уголовного преследования. Только за 6 месяцев 1925 г. в не самом крупном в Сибирском крае Боровском районе за сон на посту было наложено 12 взысканий милиционерами [6. Л. 8]. Всего же в период с 1926 по 1927 г. на милиционеров Сибирского края было наложено более 3 тысяч взысканий [15]. Правда, репрессивные меры не носили постоянного характера, были цикличны и не могли полностью решить кадровый вопрос.

Таким образом, проблемы в деятельности милиции Западной Сибири в 1925-1932 гг. были значительны и связаны они были прежде всего с дефицитом кадров, низким уровнем материальной мотивации, отсутствием полноценной профессиональной подготовки, недостаточным контролем со стороны руководителей. Карательные меры не только не решали существовавшие проблемы, но и еще больше обостряли кадровый вопрос. В то же время нельзя не отметить, что при всей неидеальности системы органов милиции и ее сотрудников данная структура в исследуемый период в целом справлялась с выполнением поставленных задач и являлась незаменимым инструментом в процессе становления молодого советского государства. В исследуемый период комплексного решения существовавших проблем найти так и не удалось, однако уроки прошлого следует учитывать в процессе дальнейшего развития органов полиции.

\section{ЛИТЕРАТУРА}

1. Собрание Законов СССР. 1931. № 12. Ст. 85.

2. Государственный архив Новосибирской области (ГАНО). Р.-Ф. 47. Оп. 5. Д. 30. Л. 77.

3. Суверов Е.В. История алтайской милиции (1917-1953 гг.) : учеб. пособие. Барнаул : Барнаул. юрид. ин-т МВД России, 2013. Ч. 1. С. 59.

4. Государственный архив Алтайского края (ГААК). Р.-Ф. 110. Оп. 1. Д. 31. Л. 10-30.

5. Государственный архив Новосибирской области (ГАНО). Р.-Ф. 47. Оп. 5. Д. 140.

6. ГААК. Р.-Ф. 110. ОП. 1. Д. 4.

7. ГАНО. Р.-Ф. 20. ОП. 2. Д. 162. Л. 19-20, 28.

8. ГАНО. Р.-Ф. 47. Оп. 1. Д. 950. Л. 79, 80.

9. ГАНО. Р.-Ф. 47. ОП. 1. Д. 154. Л. 86

10. ГАНО. Р.-Ф. 47. Оп. 5. Д. 44. Л. 71 об.

11. Советская Сибирь (Новосибирск). 1927. 12 ноя

12. ГАНО. Р.-Ф. 47. Оп. 5. Д. 76. Л. 8-8 об.

13. ГАНО. Р.-Ф. 20. Оп. 2. Д. 61 . Л. 61. 
14. ГАНО. Р.-Ф. 47. Оп. 5. Д. 72. Л. 185-186.

15. Коммуна (Татарск). 1930. 28 авг.

Kuznetsov Denis E. Altai State Technical University (Barnaul, Russian Federation). E-mail: goodjobman@inbox.ru DISADVANTAGES OF THE SIBERIAN MILITIA ACTIVITY (1925-1932 years).

Keywords: Soviet militia; West Siberia; crime; problems.

On the basis of archival documents the author analyze the problems faced by local authorities in the formation of law enforcement. The article considers the process of creation and implementation of the Siberia militia. It also discusses issue related to the protection of public order by officers of the Soviet militia in the end of the 20 s years and the beginning of the 30 s years of the last century. Changes in the country affected the Siberian region. In that period militia had a great number of duties. During the period of establishing of the Soviet power in Western Siberia the number of crimes, committed by militiamen has dramatically increased. The article tells about reasons of that process. First of all there was a bad financial situation in the Siberia region which made a great influence on the militiamen. One of the main problems was a shortage of qualified personnel. The number of qualified militia workers was insufficient. Many of the militiamen did not even have a primary education. The level of legal competence of militiamen was not high. There was an interrelation between the legal nihilism of militiamen and general increase in criminality. There was also a question of the weak discipline. A great number of militiamen did not understand the moral foundation of their profession. There was also a question of professional ethic. A lot of militiamen were involved in corruption schemes. Being a form of stealing, corruption in that time was a specific form of misconduct acts designed to obtain financial benefits and other personal gain in exchange for not pursuing, or selectively pursuing, an investigation or arrest. One common form of corruption in that period was soliciting and accepting bribes in exchange for not reporting about prostitution, moonshining and other illegal activities. More rarely, militiamen took part in organized crime activity themselves. Such situation negatively affected the society, including political, economic, and sociological aspects. The author pays some attention to the physical condition of Soviet militia officers which was in a low level. A special attention was paid to the problem of alcohol because a lagre number of militiamen abused alcohol. Besides there was an active process of development of the normative-legal base of the young Soviet state, in order to improve such negative tendencies. Despite the difficulties, the staff of the Western Siberia militia carried out all their duties in order to change such situation.

\section{REFERENCES}

1. Sobranie Zakonov SSSR [The Collection of Laws of the USSR], 1931, no. 12, Art. 85.

2. The State Archive of Novosibirsk Region (GANO). R.-Fund 47. List 5. File. 30. P. 77. (In Russian).

3. Suverov E.V. Istoriya altayskoy militsii (1917-1953 gg.) [The history of the Altai militia (1917-1953)]. Barnaul: Barnaul Law Institute of the Ministry of Internal Affairs of Russia Publ., 2013, pt. 1, p. 59.

4. The State Archive of Altai territory (GAAK). R.-Fund 110. List 1. File 31. P. 10-30. (In Russian).

5. The State Archive of Novosibirsk Region (GANO), R.-Fund 47. List 5. File 140. (In Russian).

6. The State Archive of Altai territory (GAAK). R.-Fund 110. List 1. File 4. (In Russian).

7. The State Archive of Novosibirsk Region (GANO). R.-Fund 20. List 2. File 162. P. 19-20, 28. (In Russian).

8. The State Archive of Novosibirsk Region (GANO). R.-Fund 47. List 1. File 950. P. 79, 80. (In Russian).

9. The State Archive of Novosibirsk Region (GANO). R.-Fund 47. List 1. File 154. P. 86. (In Russian).

10. The State Archive of Novosibirsk Region (GANO). R.-Fund 47. List 5. File 44. P. 71 ob. (In Russian).

11. Sovetskaya Sibir' (Novosibirsk), 1927, 12th November.

12. The State Archive of Novosibirsk Region (GANO). R.-Fund 47. List 5. File 76. P. 8-8 ob. (In Russian).

13. The State Archive of Novosibirsk Region (GANO). R.-Fund 20. List 2. File 61. P. 61. (In Russian).

14. The State Archive of Novosibirsk Region (GANO). R.-Fund 47. List 5. File 72. P. 185-186. (In Russian).

15. Kommuna (Tatarsk), 1930, 28th August. 